\title{
McCloskey ve Mueller’in İş Doyum Ölçeği’nin Türkçeye Uyarlanması: Geçerlik ve Güvenirlik Çalışması*
}

\author{
Gizem BAYRAKÇI ${ }^{* *}$, Emine TÜRKMEN ${ }^{* * *}$
}

\begin{abstract}
$\ddot{\mathbf{O} z}$
Giriş: İş doyumu, hemşireleri işte tutmanın önemli bir belirleyicisidir. Türkiye'de hemşirelerin iş doyumunu değerlendirmek üzere kullanılan, geçerlik ve güvenirliği sınanmış ölçeklerin sayısı sınırlıdır. Amaç: Bu metodolojik çalışma, "McCloskey ve Mueller İş̧ Doyumu Ölçeği” Türkçe formunun ülkemiz hemşireleri için geçerli ve güvenilir bir araç olup olmadığını incelemek amacıyla yapılmıştır. Yöntem: Bu çalı̧̧ma, Haziran-Ağustos 2017 tarihleri arasında İstanbul'da üç hastanede görev yapan 324 hemşire ile gerçekleştirilmiştir. Veri toplama aracı olarak "Sosyo-Demografik ve Mesleki Özellikler Formu" ile 31 maddelik "McCloskey ve Mueller İş Doyumu Ölçeği" kullanılmıştır. Bulgular: Ölçeğin kapsam geçerlilik indeksi 93 bulunmuştur. İç tutarlılık analizinde Cronbach alpha güvenirlik katsayısının tüm ölçek için .81 ; alt boyutlar için .45 ile .70 arasında olduğu belirlenmiştir. Test-tekrar test analizinde iki uygulama arasında fark bulunmamıştır $(t=.27, p$ $>$.05). Otuz bir maddenin madde-toplam puan korelasyon güvenirlik katsayıları $r=.28$ ile .49 arasında bulunmuştur. Doğrulayıcı faktör analizinde, ölçek maddelerinin kendi boyutu (sekiz alt boyutlu) ile olan faktör yükleri .36 ile .64 arasında saptanmıştır. Ölçeğin model-veri uyum değerlerinin kabul edilebilir düzeyde iyi olduğu belirlenmiştir (Ki-kare / serbestlik derecesi: 1.4, $p<.05$ ). Sonuç: McCloskey ve Mueller İş Doyumu Ölçeği”nin Türkçe formu kapsam ve yapı geçerliliği ölçütlerini karşılamaktadır. Madde analizleri ve zamana karşı değişmezlik güvenirlik ölçütlerini sağlamakla birlikte, ölçeğin alt boyutları açısından iç tutarlılık (Cronbach alfa) güvenirliğgi için çalışma yapılmasına ihtiyaç vardır.
\end{abstract}

Anahtar Sözcükler: Hemşireler, Geçerlik, Güvenirlik, İş doyumu, Ölçek.

\section{The Turkish Adaptation of the McClosky and Mueller Job Satisfaction Scale: A Reliability and Validity Study}

Background: Job satisfaction is an important factor in the retention of nurses. There are a few valid and reliable scales to evaluate job satisfaction for nurses in Turkey. Objectives: This methodological study was performed to determine whether the Turkish version of the "McCloskey and Mueller Job Satisfaction Scale/MMSS" is a valid and reliable tool for nurses in Turkey. Methods: This study was conducted with 324 nurses in three hospitals in Istanbul between June and August 2017. The study data collected using the "Descriptive Characteristics Form", and "McCloskey and Mueller Job Satisfaction Scale" consisting of 31 items. Results: The scale content validity index was 0.93 . The Cronbach's alpha reliability coefficient was 0.81 for the overall scale and ranged from 0.45 to 0.70 for the sub-dimensions. The stability of the scale over time was tested with 32 nurses twice at a 15-day interval. There was no significant difference between the two measurements. The item-total score reliability coefficient of the scale ranged between 0.28 and 0.49 . In the confirmatory factor analysis, the path coefficients of the items with their dimension (eight sub-dimensions) ranged between 0.36 and 0.64 . The goodness of fit of the model determined in the confirmatory factor analysis was at an acceptable level (Chi square / Degree of freedom: 1.4, $p<.05$ ). Conclusion: The results of this study indicated that MMSS meets the content and construct validity criteria. Although reliability tests of the MMSS, which are item analysis and stability, are acceptable range there is a need for further research to test the reliability of Cronbach alpha on the subdimensions of the MMSS.

Key Words: Leadership, Transformational Leadership, Nurse Manager, Unit Charge Nurses.

Geliş tarihi: 25.10.2019 Kabul tarihi: 03.06.2020

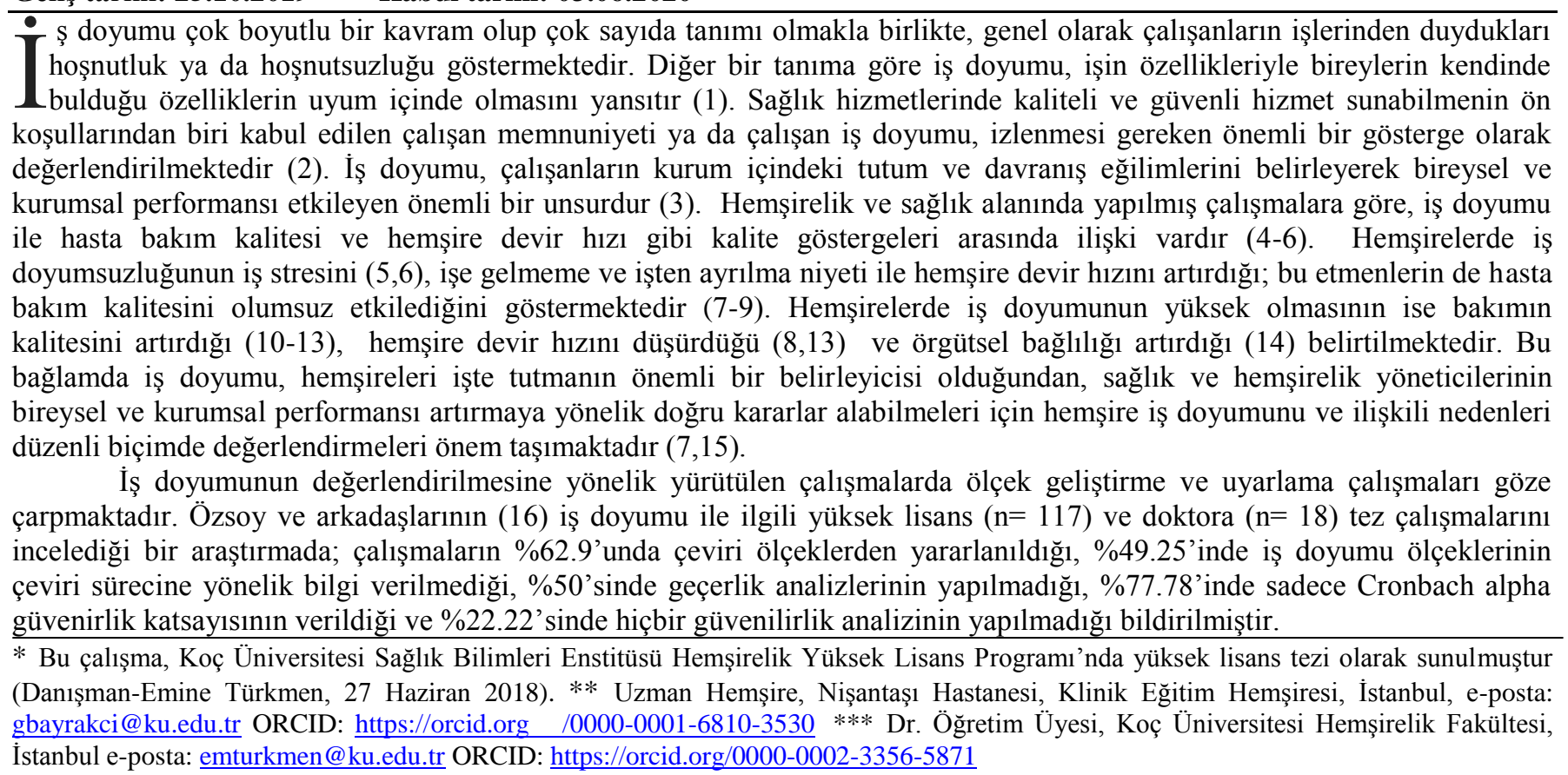


Örneğin, en sık kullanılan iş doyum ölçeğinin "Minnesota İş Doyumu Ölçeği/MỉDÖ” 20 maddeli kısa formunun (\%35.9) olduğu, bunun da Baycan (1985) tarafindan sadece İngilizceden Türkçeye çevirisi yapılarak kullanıldığı ifade edilmiştir (16). Literatür incelemesinde, hemşirelik çalışmalarında da MiDÖ’nin sıklıkla kullanıldığı (17-21); çeviri ölçeğin kullanıldığı bu çalışmalarda Özsoy ve arkadaşlarının (16) bulgularına benzer biçimde ölçeğin uyarlanmasına yönelik bilgilere yer verilmediği, farklı araştırmacılar tarafından yapılmış çalışmalar ve/veya mevcut çalışmadaki Cronbach alpha değerlerinin sunulduğu belirlenmiştir. İş doyumunun değerlendirilmesinde kullanılan diğer bir ölçek ise 1997 yılında Ergin (22) tarafından, içinde hemşire ve hekimlerin de yer aldığı çeşitli meslek gruplarının oluşturduğu örneklem üzerinde uyarlaması yapılan "İş Betimlemesi Ölçeği”dir. Sağlık dışı mesleklerde ya da iş alanlarında sık kullanılan (23-25) bu ölçek, 2009 yılında hekimler üzerinde yürütülen bir çalışma ile yedi alt boyut ve 45 madde şeklinde yeniden düzenlenmiştir $(22,26,27)$. Ancak, bu ölçeğin hemşire örnekleminde kullanıldığı bir çalışmaya rastlanmamıştır. Uyarlaması 2016 yılında Yılmaz ve Yıldırım tarafından yapılan, Muya ve arkadaşlarının (2014) Japonya'da geliştirdiği Hemşire İş Doyum Ölçeği ise 28 madde ve dört alt boyutu $(28,29)$ ile İş Betimlemesi Ölçeği (22) ve McClosky ve Müller İş Doyum Ölçeği'ne (30) göre daha az sayıda alt boyuta sahip olma özelliği taşımaktadır.

Bu çalışma için tercih edilen McClosky ve Müller İş Doyum Ölçeği (1990) ise Kanada'da geliştirilmiş ve sonrasında farklı ülkelerde kullanımı yaygınlaşmıştır (11,31-35). Ölçeğin hemşireler için geliştirilmiş olması, alt boyutları ile iş doyumunu kapsamlı biçimde değerlendirmesi, ifadelerinin kısa olup hızla yanıt verilebilmesi ve farklı ülkelerde kullanılıyor olması tercih edilmesinde etkili olmuştur. Ölçek, 1974 yılında Kanada'da McCloskey tarafindan 36 madde olarak geliştirilmiş; 1990 yllında Mueller ve McCloskey'nin yaptığı açıklayıcı faktör analizi çalışması ile sekiz alt boyut ve toplam 31 madde olarak tanımlanmıştır. Ölçek geliştirilirken, Maslow ihtiyaçlar hiyerarşisi ve Burns'un motivasyon teorisi esas alınarak bireylerin fizyolojik ve psikolojik motivasyon ihtiyaçları ile teşvik edilme ve hedeflere ulaşma arzuları dikkate alınmıştır (30). Bu bağlamda sekiz alt boyut; güvende olma (dışsal ödüller, çalışma zamanı/çizelgeler, aile iş dengesi), sosyal ödüller (iş arkadaşları, etkileşim) ve psikolojik ödüller (mesleki gelişim firsatları, özerklik-sorumluluk, tanınma-takdir görme) şeklinde teorik alt yapıyı destekleyecek biçimde tasarlanmıştır. Hemşire iş doyumunu farklı boyutları ile kapsamlı şekilde değerlendiren bu sekiz alt boyutlu ölçek, sadece hastanelerde değil ruh sağlığı, halk sağlığı, evde bakım, rehabilitasyon ve ayaktan sağlık hizmetleri gibi alanlarda da hemşirelerin iş doyumunun değerlendirilmesinde kullanılmaktadır $(30,34)$.

Amaç

Bu çalışma, Mccloskey ve Mueller İş Doyum Ölçeği’nin Türkçe formunun geçerlik ve güvenirliğini incelemek amacıyla yapılmıştır.

Araştırmanın Tipi, Yeri ve Zamanı

Yöntem

Bu araştırma, metodolojik nitelikte bir çalışma olup İstanbul'da iki özel ve bir kamu hastanesinde, Haziran-Ağustos 2017 tarihleri arasında gerçekleştirilmiştir.

\section{Araștırmanın Örneklemi}

Ölçek geçerlik ve güvenirlik çalışmalarında örneklemin ölçek madde sayısının 10 katı olması ve/veya en az 200-300 kişiye ulaşılması önerilmektedir (36). Test-tekrar test değerlendirmesinin yapılabilmesi için de en az 30 çift veri olması gerektiği bildirilmektedir (37). Bu çalışmada, ölçek madde sayısı esas alınarak $310(31 \times 10=310)$ hemşireye ulaşılması hedeflenmiştir. Çalışmanın yapıldığı hastanelerde toplam hemşire sayısı 1230 olup en az bir yılını dolduran hemşire sayısı ise 860'tır. Hedef örneklem sayısına ulaşmak amacıyla yoğun bakım, yatan hasta servisleri, acil servisler ve polikliniklerinde en az bir yıl süre ile görev yapan, araştırmaya katılmayı kabul eden 350 hemşireye (iki özel hastaneden 120'şer hemşire, devlet hastanesinden 110 hemşire) anket dağıtılmış ve veri formlarını eksiksiz dolduran 324 hemşirenin verisi kullanılmıştır. İlave olarak test-tekrar test uygulaması için örneklemi temsil eden 40 hemşireye form dağıtılmış ve ilk formu dolduran 32 hemşireye 15 gün ara ile ikinci uygulama yapılmıştır.

\section{Veri Toplama Aract}

Veri toplama aracı olarak iki bölümden oluşan anket formu kullanılmıştır. Anket formunun birinci bölümünde katılımcıların sosyo-demografik ve mesleki özelliklerinin değerlendirildiği 14 soru, ikinci bölümünde ise ölçek maddeleri yer almıştır. Beşli Likert tipindeki ölçeğin ifadelerine, "1-Hiç Memnun Değilim", "2-Memnun Değilim", "3-Biraz Memnunum", "4Memnunum" ve "5-Çok Memnunum" seçenekleri ile yanıt verilmektedir. Ölçek, 1990 yllında Mueller ve McCloskey'nin yaptığı açıklayıcı faktör analizi çalışması ile sekiz alt boyut ve 31 madde olarak yeniden düzenlenmiştir. Orijinal ölçeğin iç tutarlılık Cronbach alpha katsayısı .89 bulunmuş olup, alt boyutları ve Cronbach alpha katsayıları ise dışsal ödüller için .52 , çalışma zamanı için . 84 , aile-iş dengesi için .57, iş arkadaşları için .54, etkileşim firsatları için .72, mesleki gelişim firsatları için .64 , tanınma ve takdir görmek için .80, özerklik ve sorumluluk için .80 şeklinde belirlenmiştir. Ölçek, toplam ve alt boyutlarda ifadelere verilen yanıtların puanları toplanarak elde edilen puanın madde sayısına bölünmesi ile puanlanmaktadır. Puanın artması iş doyumunun arttığını, azalması ise iş doyumunun azaldığını ifade etmektedir (30).

\section{Verilerin Toplanmast}

Veri toplama Haziran-Ağustos 2017 tarihleri arasında yapılmıştır. Veri toplama formunu doldurmak yaklaşık 10 dakika sürmektedir. Form örnekleme alma kriterini karşılayan, çalışmaya katılımda gönüllü olan hemşireler ile yüz yüze görüşülerek kendilerine elden verilmiş ve bir hafta içinde geri toplanmıştır.

\section{Verilerin Analizi ve Değerlendirmesi}

McCloskey ve Mueller İş Doyum Ölçeği'nin geçerlik ve güvenirliğine ilişkin istatistiksel analizler, Statistical Package for the Social Sciences (SPSS) 22.0 programında yapılmıştır. Çalışmada katılımcıların tanımlayıcı özellikleri ve ölçek puanlarının tanımlayıcı istatistikleri için sayı, yüzde, ortalama ve standart sapma kullanılmıştır. Ölçeğin kapsam geçerlik analizi için 10 uzmandan alınan görüşler Davis tekniği kullanılarak kapsam geçerlik indeksi (KGI) hesaplanmış ve sınır değer olarak .80 
alınmıştır (38). Ayrıca uzmanlar arasındaki görüş birliğini incelemek üzere sınıflar arası korelasyon katsayısına (SKK= Interclass Correlation Coefficient-ICC) bakılmıştır. Ölçeğin orijinal ölçeğe benzer yapıda olup olmadığını değerlendirmek üzere doğrulayıcı faktör analizi (DFA) uygulanmıştır. Ölçeğin iç tutarlığı Cronbach alpha katsayısı ve Pearson korelasyon analizi ile incelenmiştir. Ölçeğin kararlılığı ya da zamana karşı değişmezliği ise bağımlı gruplarda t testi, Pearson korelasyon analizi ve SKK ile değerlendirilmiştir. İstatistiksel anlamlılık düzeyi $p<.05$ olarak kabul edilmiştir.

\section{Araştırmanın Etik Yönü}

Ölçeğin kullanım hakkı için Sharon Sweeney'den e-posta yolu ile izin alınmıştır. Ayrıca çalışma öncesinde etik kurul onayı 30.12.2015 tarihinde (2015.303.IRB3.175) ve çalışmanın yapıldı̆̆ $\breve{1}_{1}$ hastanelerin yöneticilerinden yazılı izin (21.06.2017) tarihinde alınmıştır. Örnekleme alınan hemşirelere uygulama öncesi açıklama yapılarak yazılı onamları alınmıştır. 


\section{Bulgular}

Araştırmaya katılan hemşirelerin yaş ortalaması $28.9 \pm 4.2$ olup \%88'i kadın, \%63.0'1 lisans mezunu ve \%66.7'si evli olduğunu bildirmiştir. Çalışmaya katılan hemşirelerin \%75.9'u servis hemşiresi olarak, \%56.2'si dahiliye-cerrahi servislerinde ve \%81.2'si karma biçimde gece ve gündüz vardiyalarında çalışmaktadır. Hemşirelerin \% 74.1 'i haftada 48 saat ve altında, \%79.3'ü günde 12 saatlik vardiyada çalışmakta olup, ancak sadece \%2.2'si vardiya saatlerinin esnek olduğunu belirtmiştir. Ayrıca hemşirelerin \%45.7'sinin mesleki deneyimi, \%47.2'sinin kurum deneyimi ve \%50'sinin bölüm deneyimi 3-5 y1l arasındadır. Hemşirelerin \%62.4'ünün geliri giderlerine denk olduğunu ifade etmiştir (Tablo 1).

Tablo 1. Hemşirelerin Sosyo- Demografik ve Mesleki Özelliklerine Göre Dağılımı (n=324)

\begin{tabular}{|c|c|c|c|}
\hline \multicolumn{2}{|l|}{ Kişisel ve Mesleki Özellikler } & \multirow{2}{*}{$\frac{\mathbf{n}}{233}$} & \multirow{2}{*}{$\begin{array}{c}\% \\
71.9\end{array}$} \\
\hline Yaş & 23-30 yaş & & \\
\hline & $>30$ yaş & 91 & 28.1 \\
\hline \multicolumn{4}{|c|}{ Yaş: $\overline{\mathbf{X}} \pm \operatorname{SS}(28.9 \pm 4.2)$, En küçük-en büyük (23-42) } \\
\hline \multirow[t]{2}{*}{ Cinsiyet } & Kadin & 285 & 88.0 \\
\hline & Erkek & 39 & 12.0 \\
\hline \multirow[t]{3}{*}{ Eğitim Düzeyi } & Sağlık meslek lisesi & 28 & 8.6 \\
\hline & Lisans & 204 & 63.0 \\
\hline & Yüksek lisans / doktora & 91 & 28.4 \\
\hline \multirow[t]{2}{*}{ Medeni Durum } & Bekâr & 108 & 33.3 \\
\hline & Evli & 216 & 66.7 \\
\hline \multirow[t]{2}{*}{ Hastane Türü } & Özel hastane & 253 & 78.1 \\
\hline & Kamu hastanesi & 71 & 21.9 \\
\hline \multirow[t]{4}{*}{ Birimdeki pozisyon } & Hemşire & 246 & 75.9 \\
\hline & Ekip lideri hemşire & 53 & 16.4 \\
\hline & Sorumlu/Eğitim hemşiresi & 16 & 4.9 \\
\hline & Eğitim hemşiresi & 9 & 2.8 \\
\hline \multirow[t]{5}{*}{ Çalışma alanı } & Yatan hasta servisi & 182 & 56.2 \\
\hline & Yoğun bakım & 72 & 22.2 \\
\hline & Poliklinik & 44 & 13.6 \\
\hline & Acil & 17 & 5.2 \\
\hline & Ameliyathane & 9 & 2.8 \\
\hline \multirow[t]{2}{*}{ Vardiya şekli } & Sadece gündüz & 61 & 18.8 \\
\hline & Gündüz ve gece (karma) & 263 & 81.2 \\
\hline \multirow[t]{2}{*}{ Haftalık çalışma süresi } & 48 saat ve altında & 240 & 74.1 \\
\hline & 48 saat üzerinde & 84 & 25.9 \\
\hline \multirow[t]{4}{*}{ Günlük çalışma süresi } & 8 saatlik vardiya & 52 & 16.0 \\
\hline & 12 saatlik vardiya & 257 & 79.3 \\
\hline & 9 saatlik vardiya & 8 & 2.5 \\
\hline & Vardiya saatleri esnek & 7 & 2.2 \\
\hline \multirow[t]{4}{*}{ Hemşirelikte çalışma süresi } & $\leq 2$ yil & 39 & 12.0 \\
\hline & $3-5$ y1l & 148 & 45.7 \\
\hline & $6-10 \mathrm{y} 1 \mathrm{l}$ & 79 & 24.4 \\
\hline & $\geq 11$ y1l & 58 & 17.9 \\
\hline \multirow[t]{3}{*}{ Kurumda çalışma süresi } & $1-2 \mathrm{y} 11$ & 117 & 36.1 \\
\hline & $3-5$ y1l & 153 & 47.2 \\
\hline & $\geq 6$ y1l & 54 & 16.7 \\
\hline \multirow[t]{3}{*}{ Ünitede çalışma süresi } & $\leq 2 \mathrm{y} 1 \mathrm{l}$ & 130 & 40.1 \\
\hline & $3-5$ y1l & 162 & 50.0 \\
\hline & $\geq 6$ y1l & 32 & 9.9 \\
\hline \multirow[t]{3}{*}{ Gelir Düzeyi } & Gelirim giderimden fazla & 24 & 7.4 \\
\hline & Gelirim ve giderim denk & 202 & 62.4 \\
\hline & Gelirim giderimden az & 98 & 30.2 \\
\hline
\end{tabular}




\section{Dil ve kapsam geçerliği}

McCloskey ve Mueller İş Doyum Ölçeği’nin dil geçerliğini sağlamak amacıyla ölçek, anadili Türkçe olup İngilizceyi anadili düzeyinde bilen bir tercüman ve iki akademisyen tarafından Türkçeye çevrilmiştir. Elde edilen çeviriler araştırmacılar tarafından tek bir metin haline getirilmiştir. Türkçeye çevrilen ölçek, anadili İngilizce olan ve Türkçeyi anadili gibi konuşup yazabilen bir başka çevirmen tarafından İngilizceye geri çevrilmiştir.

McCloskey ve Mueller'in İş Doyum Ölçeği'nin Türkçe metni kapsam geçerliliği için uzman görüşüne sunulmuştur. Uzman grup, hemşirelikte ya da sağlık alanında yönetim-liderlik dersi veren ve iş doyumu konusunda araştırmaları olan ikisi sağlık yönetimi, sekizi hemşire öğretim üyesi veya araştırma görevlisi olmak üzere 10 kişiden oluşmaktadır. Kapsam geçerliğinin sayısal değerlerle kanıtlanması için uzmanlara Likert tipi bir derecelendirme çizelgesi oluşturulmuş ve kendileri ile e-posta yolu ile iletişime geçilmiştir. Uzman kişilerin her madde için "1 = Uygun Değil; 2 = Biraz Uygun, İfadelerin Uygun Şekle Getirilmesi Gerekli; 3 = Uygun, İfade İçin Ufak Değişiklikler Gerekli; 4 = Kesinlikle Uygun” şeklinde değerlendirme yapması istenmiştir.

Uzmanlar tarafından, ölçekte bazı ifadelerde anlaşılırlık ve açıklık konusunda değişiklikler yapılması önerilmiştir. Bunlardan ilki, tüm ölçek maddelerinin birinci tekil şahıslara hitap edecek şekilde yazılması, ikincisi maddelerin anlaşılabilirlik açısından içeriklerinin düzenlenmesi $(2,3,5,7,9,10,11,12,13,16,17,18,19,20,21,25,26,27,28$ ve 31. maddeler) olup ölçek maddeleri anlaşılır hale getirilmiştir (Ek Tablo 1). İlave olarak uzmanlardan 6. madde ile 30. maddenin anlaşılmadığı belirtilmiş olup bu madde ifadelerine yönelik ölçeğin kullanım hakkı bulunan Sayın Sweeney’den açıklama talebinde bulunulmuştur. Sweeney'den 6. madde için gelen yanıt "düzenli çalışma, vardiyalara girmeden sadece gündüzleri düzenli biçimde çalışma" şeklinde olduğundan bu madde "düzenli çalışma olanağı sağlanmasından (gündüz vardiyası)" şeklinde değiştirilmiştir. Otuzuncu madde için gelen yanıt ise "işi nasıl yapacağınız konusunda karar verme becerisi”" şeklinde olduğundan bu madde de "işi nasıl yapacağımla ilgili karar verebilmekten” şeklinde değiştirilmiştir. Türkçe formda yapılan bu değişiklikler doğrultusunda ilgili maddelerin İngilizce geri çevirisi yeniden düzenlenmiştir.

Uzmanların maddelere verdiği yanıtlar üzerinden KGİ değeri hesaplanmış (3 veya 4 veren uzman sayıs1/görüş alınan uzman sayısı); üç maddenin (madde 6,16 ve 22) KGİ değerinin $<0.80$ olduğu görülmüş ve yukarıda belirtilen düzeltmeler yapılarak hesaplanan toplam ölçek KGI değerinin .93 olduğu belirlenmiştir. İlave olarak uzman görüşleri arasındaki uyumu değerlendirmek amacıyla veriler üzerinden hesaplanan SKK .90 olarak bulunmuştur $(F=10.24 ; p<.001)$. Ayrıca, 10 hemşire ile pilot çalışma yapılarak ölçek anlaşılırlığı değerlendirilmiş, pilot gruptaki hemşireler anketin anlaşılır olduğunu bildirmiştir.

\section{Yapı geçerliği}

McCloskey ve Mueller İş Doyumu Ölçeği'nin Türkçe formunun yapı geçerliği için DFA yapılmış, uyum değerleri Tablo 2'de ve yol (path) diyagramı Şekil 1'de verilmiştir. DFA sonucunda elde edilen sekiz boyutlu modelin ilk faktörüne ait madde faktör yükleri .42 ile .59 , ikinci faktörüne ait madde faktör yükleri .48 ile .64, üçüncü faktörüne ait madde faktör yükleri .46 ile .57, dördüncü faktörüne ait madde faktör yükleri .60 ile .62, beşinci faktörüne ait madde faktör yükleri .45 ile .53 , altınc1 faktörüne ait madde faktör yükleri .36 ile .46 , yedinci faktörüne ait madde faktör yükleri .39 ile .61 ve sekizinci faktörüne ait madde faktör yükleri ise .48 ile .53 arasında değer almıştır. DFA analizi ve path diyagramının da işaret ettiği değerler dikkate alınarak tüm maddeler ölçekte bırakılmış ve güvenirlik çalışmalarına geçilmiştir.

Tablo 2. McCloskey ve Mueller İş Doyumu Ölçeği'nin Doğrulayıcı Faktör Analizi: Model-Veri Uyum Değerleri (n=324)

\begin{tabular}{ll}
\hline DFA Uyumluluk İstatistiği & DFA Uyum Değerleri \\
\hline Ki-kare/ $p$ değeri & $\mathbf{5 6 5 . 8 5 / . 0 0 0}(p<.05)$ \\
Ki-kare: serbestlik derecesi & $565.85: 405=1.40$ \\
RMSEA / $p$ & $.035 /(p<.05)$ \\
SRMR & .054 \\
CFI & .94 \\
NFI & .93 \\
GFI & .90 \\
AGFI & .88
\end{tabular}

RMSEA: Root Mean Square Error of Approximation (Yaklaşık Hataların Ortalama Karekökü), SRMR: Standardized Root-mean-Square Residual (Standardize Ortalama Hataların Karekökü), CFI: Comparative Fit Index (Karşılaştırmalı Uyum İndeksi), NFI: Non-normed Fit Index (Non-normed Uyum İndeksi), GFI: Goodness of Fit Index (Uyum İyiliği İndeksi), AGFI: Adjusted Goodness of Fit Index (Düzeltilmiş Uyum İyiliği İndeksi)

\section{Güvenirlik testleri}

McCloskey ve Mueller İş Doyumu Ölçeği'nin Türkçe formunun güvenirliğini incelemek üzere iç tutarlılık (madde analizleri ve Cronbach alfa) ve kararlılık durumu değerlendirilmiştir.

Madde analizleri: McCloskey ve Mueller İş Doyumu Ölçeği'nin Türkçe formumun 31 maddesinin madde-toplam puan incelemesinde, korelasyon katsayılarının $r=.28$ ile .49 arasında, pozitif yönde ve istatistiksel olarak anlamlı olduğu saptanmıştır. Sekiz alt boyutunun madde-alt boyut toplam puanları arasındaki ilişkinin incelenmesinde; güvenirlik katsayıları dışsal ödüllerden memnuniyet alt boyutunda $r=.65$ ile .75 , çalışma zamanından memnuniyet alt boyutunda $r=.56$ ile .72 , aile ve iş dengesinden memnuniyet alt boyutunda $r=.66$ ile .76 , iş arkadaşlarından memnuniyet alt boyutunda $r=.79$ ile .86 , etkileşim firsatlarından memnuniyet alt boyutunda $r=.63$ ile .69 arasında, mesleki gelişim firsatlarından memnuniyet alt 
boyutunda $r=.60$ ile .62 arasında, tanınma ve takdir görmekten memnuniyet alt boyutunda $r=.58$ ile .67 arasında, özerklik ve sorumluluktan memnuniyet alt boyutunda $r=.51$ ile .69 arasında olmak üzere pozitif yönde ve istatistiksel olarak anlamlı bulunmuştur. Ölçeğin sekiz alt boyut puanı-toplam ölçek puan korelasyon katsayısının ise $r=.45$ ile .63 arasında, pozitif yönde ve istatistiksel olarak anlamlı olduğu belirlenmiştir $(p<.001$, Tablo 3$)$.

Cronbach alfa katsayısı: McCloskey ve Mueller İş Doyumu Ölçeği Türkçe formu ve alt boyutlarının güvenirlik göstergelerinden biri olan iç tutarlılığ 1 test etmek için yapılan analizde Cronbach alpha güvenirlik katsayısı tüm ölçek için 0.81 bulunmuştur. Anketin alt boyutlarının iç tutarlılık güvenirlik katsayısının ise sayısı 0.45 ile 0.70 arasında değiştiği belirlenmiştir (Tablo 3).

Kararlılık: Otuz iki hemşire ile ilk ve ikinci uygulamadan (15 gün ara ile yapılan iki ölçüm) elde edilen puanlar arasındaki ilişki Pearson korelasyon analizi/SKK ile incelendiğinde; toplam ölçek puanı ve sekiz alt boyutunun test ve tekrar test puanları arasında pozitif yönde, çok güçlü ve istatistiksel olarak anlamlı bir ilişki olduğu saptanmıştır $(r=.74$ ile .84 arası; $p<.001)$. Toplam ölçek ve alt boyutlarının test ve tekrar testten elde edilen puanlar arasındaki tutarlılık SKK toplam puan ve sekiz alt boyutu için .85 ile .89 arasında ve istatistiksel olarak anlamlı bulunmuştur $(p<.001)$. Ölçek ve alt boyutlarının iki ölçümden elde edilen puan ortalamaları bağımlı gruplarda $t$ testi ile karşılaştırıldığında, hem toplam puan hem de sekiz alt boyutunun puan ortalamaları arasında anlamlı düzeyde fark olmadığı belirlenmiştir $(p>.05$, Tablo 4).

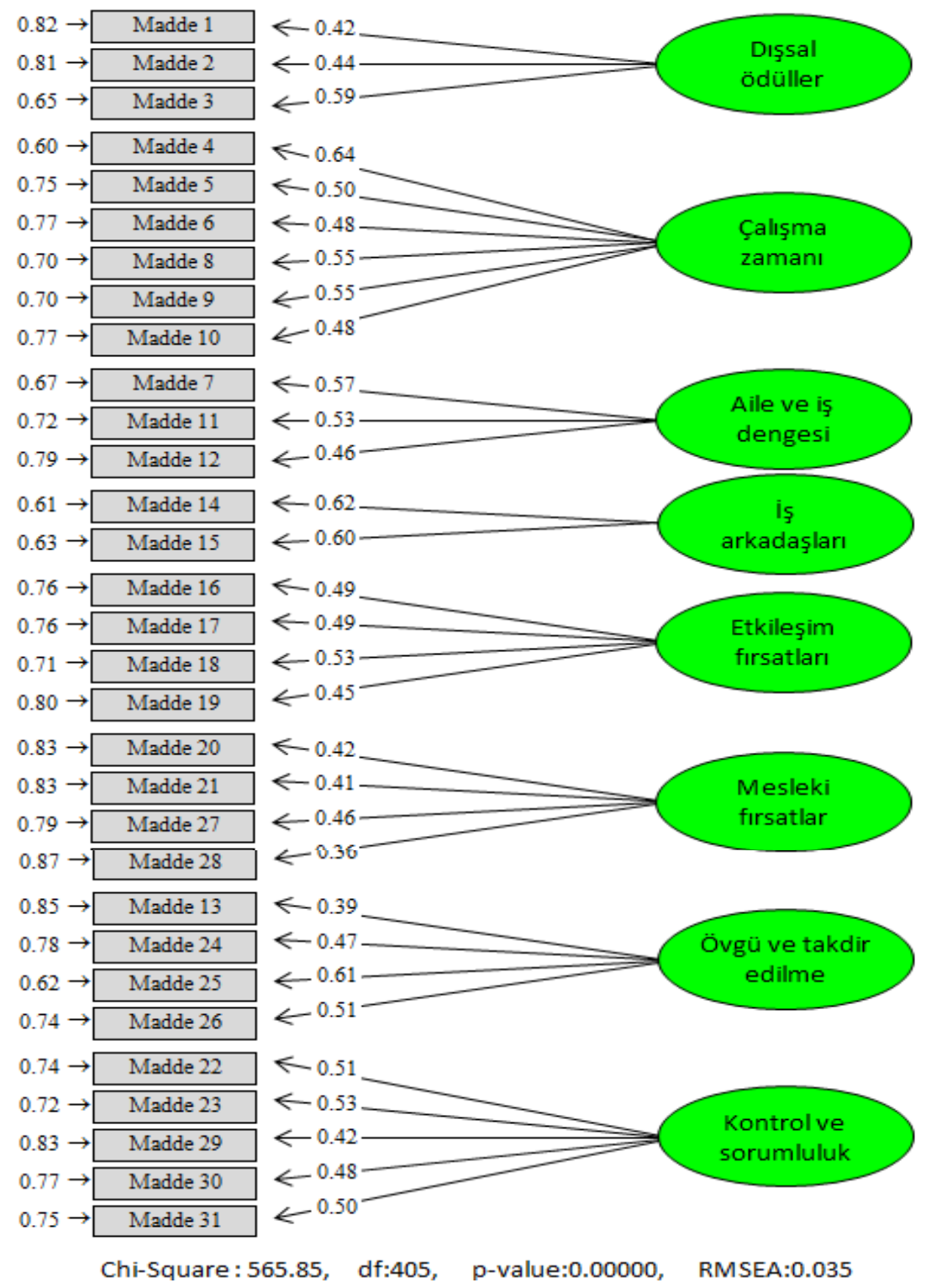

Şekil 1. McCloskey ve Mueller İş Doyumu Ölçeğinin Doğrulayıcı Faktör Analizi: Yol Katsayıları ve Hata Varyansları (n = 324) 
Tablo 3. McCloskey ve Mueller İş Doyumu Ölçeği'nin Madde-Toplam, Madde-Alt Boyut Puan ve Alt Boyut-Toplam Puan Korelasyonlart ve Cronbach Alfa Güvenirlik Katsayıları $(n=324)$

\section{Maddeler ve İfadeler}

\section{$\overline{\mathrm{x}} \begin{array}{ccc}\text { Madde- } & \text { Madde-alt } & \text { Alt Boyut- } \\ \text { toplam puan } & \text { boyut puan } & \text { toplam puan }\end{array}$ oplam puan boyut puan toplam puan}

\section{Alt boyut 1: Dışsal ödüllerden}

(3.15

1.Maaşımdan

$3.15 \pm .61$

2.İzin haklarımı istediğim şekilde kullanabilmekten

$2.96 \pm .91$

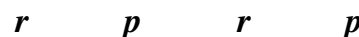

$r \quad p$

3.Ek yararlanım olanaklarımdan (sigorta, emeklilik vb.)

Alt boyut 2: Çalışma zamanından

$3.11 \pm .98$

$3.37 \pm .72$

$2.94 \pm .52$

4.Çalışma saatlerimden

$2.94 \pm .77$

5.Çalışma saatlerimi ayarlamada esnek davranılmasından

$2.83 \pm .71$

6.Düzenli çalışma olanağı sağlanmasından (gündüz

$2.94 \pm 1.04$

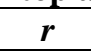

vardiyas1)

8.Aylık hafta sonu izinlerimden

$3.13 \pm .86$

.37

$\begin{array}{lll}p & \boldsymbol{p} & \boldsymbol{p}\end{array}$

$.55 \quad .000^{*}$

9.Hafta sonu izinlerimin ayarlanmasında esnek

$3.20 \pm .77$

$\begin{array}{llll}.33 & 000 * & .75 & .000 *\end{array}$

$.000^{*}$

$.69 \quad .000 *$

$\alpha=.47$

davranılmasindan

10.Hafta sonu çalışmalarım için ek kazanç

sağlanmasından (ücret/izin)

\begin{tabular}{l} 
Alt boyut 3: Aile ve iş dengesinden \\
$\begin{array}{l}\text { 7.Yarı zamanlı çalışma olanağı sağlanmasından } \\
\text { (kurumda sağlanan olanaklar) }\end{array}$ \\
$\begin{array}{l}\text { 11.Doğum için verilen izni kullanabilmekten (kurumda } \\
\text { sağlanan olanaklar) }\end{array}$ \\
\hline 12.Çocuk bakımı için sağlanan olanaklardan \\
\hline Alt boyut 4: İş arkadaşlarından \\
14.Birlikte çalıştığım hemşirelerden \\
15.Birlikte çalıştığım hekimlerden
\end{tabular}

\section{Alt boyut 5: Etkileşim firsatlarından}

16.Çalıştı̆̆ım birimde kullanılan bakım sunum

$2.61 \pm .73$

$.49000^{*}$

.65

$000 *$

yöntemlerinden (fonksiyonel, ekip, primer hemşirelik,

$3.06 \pm .61$

$2.78 \pm .74$

$\begin{array}{llll}.44 & 000 * & .66 & .000 *\end{array}$

$\begin{array}{llll}.34 & 000 * & .56 & .000 *\end{array}$

$\alpha=.70$

hasta paylaşma)

\begin{tabular}{|c|c|c|c|c|c|c|}
\hline 17.İş yerimde sağlanan sosyal etkileşim olanaklarından & $3.03 \pm .85$ & .41 & $000 *$ & .63 & $.000 *$ & \\
\hline $\begin{array}{l}\text { 18.İ̀s dışında meslektaşlarımla sosyal etkileşim } \\
\text { fırsatlarından }\end{array}$ & $3.02 \pm .91$ & .47 & $000 *$ & .69 & $.000 *$ & \\
\hline 19.Diğer disiplinlerle mesleki etkileşim firsatlarından & $3.12 \pm .88$ & .41 & $000 *$ & 63 & $.000 *$ & \\
\hline Alt boyut 6: Mesleki gelişim fursatlarından & $2.86 \pm .64$ & & & & & $.000 *$ \\
\hline $\begin{array}{l}\text { 20.Hemşirelik okullarındaki öğretim elemanları ile } \\
\text { etkileşim fırsatlarından }\end{array}$ & $3.16 \pm 1.06$ & .43 & $000 *$ & .62 & $.000 *$ & \multirow[t]{4}{*}{$\alpha=.45$} \\
\hline $\begin{array}{l}\text { 21.Çalıştığım bölüm/kurumdaki komitelerde yer alma } \\
\text { fırsatlarından }\end{array}$ & $3.08 \pm 1.10$ & .41 & $000 *$ & .62 & $.000 *$ & \\
\hline $\begin{array}{l}\text { 27.Hemşirelik araştırmalarına katılmam için sağlanan } \\
\text { olanaklardan }\end{array}$ & $2.65 \pm 1.00$ & .40 & $000 *$ & .62 & $.000 *$ & \\
\hline 28.Yazma ve yayın yapmam için sağlanan olanaklardan & $2.56 \pm .98$ & .29 & $000 *$ & 60 & $.000 *$ & \\
\hline Alt boyut 7: Tanınma ve takdir görmekten & $2.95 \pm .57$ & & & & & $.000^{*}$ \\
\hline 13.Yöneticimden (bir üst amirimden) & $3.13 \pm .75$ & .29 & $000 *$ & .58 & $.000 *$ & \multirow{4}{*}{$\alpha=.56$} \\
\hline 24.Yöneticiler tarafindan takdir edilmekten & $2.56 \pm .93$ & .34 & $000 *$ & .67 & $.000 *$ & \\
\hline $\begin{array}{l}\text { 25.Birlikte çalıştığım meslektaşlarım tarafından takdir } \\
\text { edilmekten }\end{array}$ & $3.35 \pm .76$ & .47 & $000 *$ & .67 & $.000 *$ & \\
\hline 26.Cesaretlendirilmekten ve aldığım geribildirimlerden & $2.77 \pm 1.03$ & .39 & $000 *$ & 61 & $.000 *$ & \\
\hline Alt boyut 8: Özerklik ve sorumluluktan & $2.98 \pm .58$ & & & & & $.000 *$ \\
\hline 22.Çalışma ortamında olanları kontrol edebilmemden & $3.03 \pm 1.04$ & .41 & $000 *$ & .66 & $.000 *$ & \multirow{5}{*}{$\alpha=.60$} \\
\hline 23.Kariyer gelişim firsatlarından & $2.98 \pm 1.09$ & .41 & $000^{*}$ & .69 & $.000 *$ & \\
\hline 29.Sorumluluk düzeyimden & $3.13 \pm 1.10$ & .32 & $000 *$ & .66 & $.000 *$ & \\
\hline 30.İşimi nasıl yapacağımla ilgili karar verebilmekten & $2.99 \pm .67$ & .41 & $000 *$ & .51 & $.000^{*}$ & \\
\hline 31.Örgütsel kararlara katılmaktan & $2.79 \pm .69$ & .38 & $000 *$ & .57 & $.000 *$ & \\
\hline
\end{tabular}

$\begin{array}{lllll}3.12 \pm .89 & .35 & 000 * & .76 & .000 *\end{array}$

$\alpha=.53$

\begin{tabular}{ccccccc}
$3.28 \pm .89$ & .28 & $000^{*}$ & .74 & $.000^{*}$ & & \\
\hline $3.29 \pm .68$ & & & & & .51 & $.000^{*}$ \\
$3.50 \pm .74$ & .41 & $000^{*}$ & .79 & $.000^{*}$ & $\alpha=.54$ \\
$3.07 \pm .89$ & .44 & $000^{*}$ & .86 & $.000^{*}$ & & \\
\hline $3.08 \pm .59$ & & & & & .62 & $.000^{*}$ \\
\hline $3.17 \pm .95$ & .35 & $000^{*}$ & .67 & $.000^{*}$ & \\
& & & & & & $\alpha=.56$
\end{tabular}

17.İş yerimde sağlanan sosyal etkileşim olanaklarından

$3.03 \pm .85$

$\begin{array}{llll}.41 & 000^{*} & .72 & .000^{*}\end{array}$

$\begin{array}{llll}.43 & 000 * \quad .67 & .000 *\end{array}$


Tablo 4. McCloskey ve Mueller İş Doyumu Ölçeği ve Alt Boyutlarının Test-Tekrar Test Puan Ortalamalarının Karşıllaşttrılması ve Korelasyonları $(n=32)$

\begin{tabular}{lccccccc}
\hline $\begin{array}{l}\text { Ölçek ve Alt } \\
\text { Boyutlar }\end{array}$ & Illk uygulama & $\begin{array}{c}\text { Ikinci } \\
\text { uygulama }\end{array}$ & $\boldsymbol{r}$ & SKK & $\boldsymbol{p}$ & $\boldsymbol{t}$ & $\boldsymbol{p}$ \\
\hline Toplam ölçek & $3.52 \pm .29$ & $3.52 \pm .38$ & .84 & .89 & $.000^{*}$ & .027 & $.979^{* *}$
\end{tabular}

\begin{tabular}{llllllll}
\hline Ölçek Alt Boyutları & & & & & & & \\
\hline $\begin{array}{l}\text { 1.Dişsal ödüllerden } \\
\text { memnuniyet }\end{array}$ & $3.43 \pm .42$ & $3.35 \pm .54$ & .78 & .86 & $000^{*}$ & 1.228 & $.229^{* *}$ \\
\hline $\begin{array}{l}\text { 2.Calışma zamanından } \\
\text { memnuniyet }\end{array}$ & $3.27 \pm .60$ & $3.35 \pm .60$ & .76 & .86 & $000^{*}$ & 1.060 & $.297^{* *}$ \\
\hline $\begin{array}{l}\text { 3.Aile ve iş dengesinden } \\
\text { memnuniyet }\end{array}$ & $3.44 \pm .50$ & $3.46 \pm .45$ & .74 & .85 & $000^{*}$ & .340 & $.736^{* *}$ \\
\hline $\begin{array}{l}\text { 4.İs arkadaşlarından } \\
\text { memnuniyet }\end{array}$ & $3.95 \pm .54$ & $3.84 \pm .51$ & .78 & .88 & $000^{*}$ & 1.752 & $.090^{* *}$ \\
\hline $\begin{array}{l}\text { 5.Etkileşim firsatlarından } \\
\text { memnuniyet }\end{array}$ & $3.63 \pm .45$ & $3.55 \pm .50$ & .74 & .85 & $000^{*}$ & 1.407 & $.169^{* *}$ \\
\hline $\begin{array}{l}\text { 6.Mesleki gelişim } \\
\text { firsatlarından memnuniyet }\end{array}$ & $3.49 \pm .53$ & $3.53 \pm .67$ & .76 & .85 & $000^{*}$ & .502 & $.619^{* *}$ \\
\hline $\begin{array}{l}\text { 7.Tanınma ve takdir } \\
\text { görmekten memnuniyet }\end{array}$ & $3.57 \pm .62$ & $3.50 \pm .84$ & .83 & .88 & $000^{*}$ & .828 & $.414^{* *}$ \\
\hline $\begin{array}{l}\text { 8. Özerklik ve sorumluluktan } \\
\text { memnuniyet }\end{array}$ & $3.66 \pm .39$ & $3.71 \pm .48$ & .77 & .86 & $000^{*}$ & .928 & $.361^{* *}$ \\
\hline
\end{tabular}

SKK: Sınıf içi Korelasyon Katsayısı (Intraclass Correlation Coefficient/ICC), $r$ : Pearson korelasyon analizi, $t$ : Bağımlı gruplarda t testi: serbestlik derecesi $=31, * p<.001 ; * * p>.05$

\section{Tartışma}

Bu çalışmada, McCloskey ve Mueller İş Doyumu Ölçeği'nin Türkçe formunun ülkemiz hemşireleri için geçerlik ve güvenirliği sınanmıştır.

Kültürler arası ölçek uyarlama çalışmalarında ilk önerilen adım, ölçeğin dil ve kapsam geçerliğinin sağlanmasıdır. Dil geçerliği ile birlikte yürütülen kapsam geçerliği, ölçme aracının içerdiği ifadelerin ölçmeyi amaçladığı konuları ne denli dengeli şekilde temsil ettiğini değerlendirmektedir $(39,40)$. Bu süreç, "çeviri, geri çeviri, uzman paneli ve pilot çalışma" olmak üzere (ikinci ve üçüncü aşamanın sırası değișebilmekle birlikte) dört aşamada yürütülmektedir (41). Bu çalışmada, çeviri sonrası elde edilen ölçek 10 uzmana gönderilmiş; uzmanlardan gelen öneriler dikkatle incelenmiş; ölçeğin kullanım izni olan kişiden görüş alınmış; çevirmenlerle görüşülerek ölçek şekillendirilmiş ve pilot çalışma ile test edilmiş̧ir. Ölçeğin kapsam geçerliğinin sayısal değerler ile kanıtlanması için KGİ ve SKK hesaplanmıştır. Ölçeğin bütünü için hesaplanan KGİ değerinin (.93) sınır değerin (> .80) üzerinde ve SKK'nın yüksek (.90) olması ölçeğin kapsamının geçerli olduğunu göstermektedir $(42,43)$.

McCloskey ve Mueller (1990) tarafından yapılan orijinal çalışmada, teorik olarak hazırlanan ölçek yapısının geçerliği beş farklı model-veri uyumu açısından DFA ile incelenmiştir. Bu analizlerde, sınanan modellerin uyum indekslerinin düşük olduğu belirlenmiş ve açıklayıcı faktör analizi yapılmıştır. Açıklayıcı faktör analizinde 31 maddenin sekiz alt boyutta yer aldığı ve maddelerin yol katsayılarının yeterli olduğu (.28-.85 arasında) belirlenmiștir (30).

Kültürler arası ölçek uyarlama çalışmalarında, var olan kuramsal yapının geçerliğini incelemek üzere DFA yapılması önerilmektedir. DFA, model-veri uyum indekslerinin (ki-kare/p, RMSEA, SRMR, CFI, NNFI, GFI ve AGFI) ve madde-alt boyut ilişkisini gösteren yol katsayılarının değerlendirildiği bir yöntemdir (44). Uyum indekslerinden ki-kare istatistikleri doğrulayıcı modellerde serbestlik derecesi ile birlikte mutlaka raporlanması önerilen bir incelemedir; ki-kare/serbestlik derecesinin < 1'in altında olması "iyi uyum", 1-3 arasında olması "kabul edilebilir uyum" olduğunu göstermektedir. Rapor edilmesi istenen diğer uyum indeksleri arasında yer alan GFI, AGFI, CFI, NFI'nin >.90 olması; SRMR ve RMSEA'nın ise < .05 olması durumu "iyi uyum" olarak yorumlanmaktadır (45-47). Bu çalışmada model-veri uyumu RMSEA, CFI ve NFI açısından iyi uyum gösterirken, ki-kare/sd, SRMR ve AGFI $(\geq .85)$ açısından kabul edilebilir uyum değerlerine sahiptir. GFI'nin ise sınır değerde olduğu görülmektedir. DFA'da her bir maddenin alt boyutu ile olan ilişkisini yansıtan yol katsayıları için (faktör yükü) sınır değer olarak önerilen .30 değeri dikkate alındığında (48), ölçek maddeleri yeterli faktör yüküne (.36 .64) sahiptir. Bu çalışmada elde edilen model-veri uyum değerleri bütün olarak değerlendirildiğinde, ölçeğin sekiz alt boyutlu Türkçe formunun yapı açısından uygun olduğu söylenebilir.

McCloskey ve Mueller İş Doyumu Ölçeği farklı kültürlere uyarlaması mevcuttur. Ajamieh ve arkadaşları (1996) tarafından Filistin'de yapılan çalışmada açıklayıcı faktör analizi yapılmış; ölçeğin yapısı 21 madde ve dört alt boyutta toplandığı belirlenmiştir (32). El-Jardali ve arkadaşları tarafından 2009 yılında Lübnan'da, Arapça ve Fransızcaya uyarlanmış; 31 madde ve yedi alt boyut olarak kullanılmıştır (31). Yine El-Jardali ve arkadaşları tarafindan 2013 yılında kırsal bölgedeki sağlık kuruluşlarında çalışan hemşirelerin iş doyumu, altı maddesi dışlanarak 25 maddelik kısmı ile ölçüm yapılmışır (35). Kuveyt'te Al-Enezi ve arkadaşları tarafından 2009 yılında yapılan çalışmada ise kültürel olarak 21 maddenin uygun olduğu ve bu maddelerin beş alt boyutta yer aldığı bildirilmiştir (33). Abualrub ve arkadaşları (2009), Ürdün'de orijinal yapısı ile 
kullanmıştır (34). Yapılan çalışmalarda ölçek yapısında değişiklik oluşturan bu sonuçlar, yapılacak karşılaştırmalarda araştırmacılar için sinırlılık oluşturabilir.

Ölçek oluşturma ya da uyarlama çalışmalarında yapılması gereken güvenirlik testleri aynı zamanda geçerliği de desteklemektedir. Bir ölçüm aracının geçerli sayılabilmesi için güvenilir olması önkoşuldur. Diğer bir deyişle güvenirlik, ölçmesi gereken şeyi her uygulanışında aynı biçimde ölçmede gösterdiği tutarlılık derecesi olarak tanımlanmaktadır (49). Bu çalışmada, McCloskey ve Mueller İş Doyumu Ölçeği’nin güvenirliğine ilişkin kanıtlar iç tutarlılık (madde analizleri ve Cronbach Alfa) ve kararlılık (bağımlı gruplarda t testi, IKK) yönünden incelenmiştir.

Madde analizi, güvenirlik çalışmalarında iç tutarlılığın değerlendirilmesinde kullanılan yöntemlerden birisidir. Ölçeğin her maddesinin güvenirliği konusunda araştırmacıya bilgi verir. Bu analizle amaç, her bir maddenin ölçek toplam puanına katkısını değerlendirmektir. Madde-toplam puan korelasyon katsayısının alt sınırı ile ilgili literatürde farklı değerler verilmekle birlikte genel olarak en alt sınır .30 önerilmekte (36), bazı çalışmalarda ise güvenilirlik katsayısı alt sınır olarak .20 alınmaktadır (50). Bu çalışmada, madde-toplam puan korelasyon katsayısı .30'un altında olan üç madde (madde 12, 13 ve 28) vardır. Ancak bu maddelerin korelasyon katsayısı sınır değerin (.20) üzerinde olduğundan ölçekte bırakılmış olup elde edilen bu sonuçlar, maddelerin toplam ölçek puanına katkısı açısından güvenilir olduğunu göstermektedir.

Likert tipi ölçeklerin iç tutarlılık değerlendirmesinde yapılması önerilen bir diğer inceleme Cronbach alpha katsayısıdır. Güvenirlik açısından Cronbach alpha katsayısının .70 ve üzerinde olması beklenir, ancak değer ne kadar "1"e yakınsa o kadar ölçüm aracının o kadar güvenirliği artar $(36,42)$. Bu çalışmada toplam ölçek için Cronbach alpha değeri $(\alpha=.81)$ diğer çalışmalar ile benzer biçimde (30-34) yüksek bulunmuştur; ancak alt boyutlardan "çalı̧̧ma zamanından memnuniyet" hariç diğer yedi alt boyutta Cronbach alfa değeri sınır değerin altındadır. Bu çalışmada elde edilen Cronbach güvenirlik katsayılarının orijinal ölçek ile benzer biçimde, dışsal ödüller, aile-iş dengesi, iş arkadaşları ve mesleki gelişim firsatlarından memnuniyet alt boyutlarında düşük olduğu $(\alpha<.70)$ görülmektedir. İlave olarak orijinal ölçeğe göre etkileşim firsatları, tanınma ve takdir ile özerklik ve sorumluluktan memnuniyet alt boyutlarında da Cronbach alpha değerinin düşük olması dikkat çekicidir. Elde edilen bu Cronbach alpha değerleri, ölçeğin bir bütün olarak güvenirlik ölçütlerini sağladığını, ancak alt boyutları ile güvenirlik ölçütlerini karşılamadığını göstermektedir. Literatürde, ölçek ya da ölçek alt boyut madde sayısının onun altında olması durumunda Cronbach alpha değeri düşük çıkabileceği belirtilmektedir $(51,52)$. Bu çalışmada, alt boyutlardaki madde sayısının 2-6 arasında olması Cronbach alpha değerinde düşüklüğe yol açmış olabilir.

Test-tekrar test analizi, testin zamana karşı değişmezlik özelliğinin değerlendirilmesi amacı ile gerçekleştirilmektedir. Aynı ölçme aracı aynı koşullar altında, değiş̧ik zamanlarda bireye uygulandığında, bireyin ölçme aracı maddelerine verdiği yanıtların benzer yani tutarlı olması, o ölçme aracının değişmezliğini gösterir. Bu değerlendirme için önerilen testler SKK ve Pearson korelasyon katsayısıdır. Her iki test için de korelasyon katsayısı ne kadar "1"e yakınsa o kadar ilk ve ikinci ölçüm birbirine benzerdir (36). Bu çalışmada, 15 gün ara ile ölçüm yapılmış ve iki uygulama arasında elde edilen puanlar üzerinde .80 'in üzerinde korelasyon bulunmuştur. Mueller ve McCloskey'nin (1990) çalışmasında, altı ay ara ile ölçüm yapilmış ve korelasyon katsayısı .64 bulunmuştur (30). Elde edilen bu değerler, ölçeğin zamana karşı güvenilir olduğunun bir göstergesidir.

Çalışmadaki sonuçlar katılımcıların verdiği cevaplarla sınırlıdır.

\section{Kisitlılıklar}

\section{Sonuçların Uygulamada Kullanımı}

McCloskey ve Mueller İş Doyumu Ölçeği Türkçe formunun ülkemiz hemşireleri için geçerlik ve güvenirliğinin sinandığı bu çalışmada, uyarlama çalışmaları uluslararası bilimsel yöntemlere uygun olarak yapılmıştır. Öncelikle ölçeğin dil ve kapsam geçerliği sağlanmış ardından yapı geçerliği ve güvenirliği incelenmiştir. McCloskey ve Mueller İş Doyumu Ölçeği'nin hemşireler için geliştirilmiş olması, ölçekte yer alan maddelerin iş doyumu ile ilişkili kavramları içeren Maslow ihtiyaçlar hiyerarşisi ve Burns'un motivasyon kuramından yararlanılarak kapsamlı biçimde hazırlanmış olması, ifadelerinin kısa olup hızla yanıt verilebilmesi, geliştirildiği ülke dışında farklı ülkelerde kullanılıyor olması güçlü yanlarını oluşturmaktadır.

Kapsam ve yapı geçerliği sonuçları, orijinal ölçekle aynı biçimde Türkçe formun 31 maddeli ve sekiz alt boyutlu yapısının korunduğunu göstermektedir. Güvenirlik açısından ölçek alt boyutlarında düşük güvenirlik katsayısı olmakla birlikte, yapı geçerliği çalışmasında ölçeğin model-veri uyumunun iyi olması ve madde analizlerinin güvenirlik ölçütlerini karşılaması nedeniyle görüşümüz, ölçeğin Cronbach alpha değerleri yeniden hesaplanarak alt boyutlu bir ölçek olarak kullanılabileceği yönündedir. Ölçeğin puan hesabı tüm ölçek ya da alt boyut madde puan toplamlarının madde sayısına bölünerek, diğer bir ifade ile ortalaması alınarak yapılmaktadır. Ortalama puanın "5"e doğru yaklaşması iş doyumunun arttığını, "1"e doğru yaklaşması düşük olduğunu göstermektedir. Yönetici hemşireler ve araştırmacılar, elde ettikleri Cronbach alpha değerlerini baz alarak ölçeği toplam ya da alt boyutlu bir ölçek olarak hemşirelerin iş doyumunu değerlendirmede ve iş doyumsuzluğu yaratan olası sorun alanlarını belirlemede kullanabilir. Ayrıca, gelecekte yapılacak çalışmalarda, ölçeğin Cronbach alfa ile iç tutarlılık analizlerinin tekrar edilmesi ve zamana karşı değişmezlik açısından altı ay sonra değerlendirmenin yapılmasının yanı sıra hemşire iş doyumu ve sonuçlarını belirlemede en iyi iş doyumu araçlarını ortaya koymak üzere diğer iş doyumu ölçekleri ile birlikte karşılaştırma çalışmalarının yapılması önerilir. 


\section{Bilgilendirme}

Yazarların Katkı beyanı; Fikir: GBU, ET; Tasarım: GBU, ET; Denetleme: GBU, ET; Veri Toplama ve İşleme: GBU; Veri Analizi ve Yorumlama: GBU, ET; Literatür tarama: GBU, ET; Makale yazma: GBU, ET; Eleştirel inceleme: ET şeklindedir.: $\mathrm{Bu}$ çalışma için etik kurul onayı alınmıştır (No: 2015.303.IRB3.175). Araştırmaya herhangi bir fon desteği alınmamış olup, çalışma özgün araştırma türündedir ve araştırmacılar arasında çalışmaya bağlı olarak bir çıkar çatışması söz konusu değildir. Araştırmacılar, McCloskey ve Mueller İş Doyumu Ölçeği’nin kullanım iznini veren Sharon Sweeney'e, çalışmanın yapılmasına izin veren hastanelerin yöneticilerine, ölçeğe değerli görüşleri ile katkı yapan uzmanlara ve tüm katılımcılara teşekkür eder.

\section{Kaynaklar}

1. Yazıcı Altuntaş S. İş doyumu ve işten ayrılma niyeti. İçinde: Tatar Baykal Ü, Ercan Türkmen E. Hemşirelik Hizmetleri Yönetimi. İstanbul, Akademi Yayıncılık; 2014: 641-652.

2. SKS Hastane. (17/01/2017). Sağlıkta kalite standartları. Erişim: 2.09.2019 https://dosyamerkez.saglik.gov.tr/Eklenti/3460,skshastanesetiv5r1pdf.pdf?0

3. Özpehlivan M. İş tatmini: Kavramsal gelişimi, bireysel ve örgütsel etkileri, yararları ve sonuçları. Kırklareli Üniversitesi Sosyal Bilimler Dergisi 2016;2(2):43-70.

4. Kuzey C. Impact of health care employees job satisfaction on organizational performance support vector machine approach. JEFA 2018;2(1):45-68.

5. Hosseinabadi MB, Etemadinezhad S, Khanjani N, Ahmadi O, Gholinia H, Galeshi M, et al. Evaluating the relationship between job stress and job satisfaction among female hospital nurses in Babol: An application of structural equation modeling. Health Promot Perspect 2018; 8(2):102-108.

6. Erşan EE, Yıldırım G, Doğan O, Doğan S. Sağlık çalışanlarının iş doyumu ve algılanan iş stresi ile aralarındaki ilişkinin incelenmesi. Anadolu Psikiyatri Derg 2013;14:115-121.

7. Hayes LJ, O’Brien-Pallas L, Duffield C, Shamian J, Buchan J, Hughes F, et al. Nurse turnover: a literature review. Int J Nurs Stud 2006;43(2):237-263.

8. Hayes LJ, O’Brien-Pallas L, Duffield C, Shamian J, Buchan J, Hughes F, et al. Nurse turnover: a literature review-an update. Int J Nurs Stud 2012;49(7):887-905.

9. McHugh MD, Kutney-Lee A, Cimiotti JP, Sloane DM, Aiken L. H. Nurses' widespread job dissatisfaction, burnout, and frustration with health benefits signal problems for patient care. Health Aff 2011;30(2):202-210.

10. Koy V, Yunibhand J, Angsuroch Y, \& Fisher ML. Relationship between nursing care quality, nurse staffing, nurse job satisfaction, nurse practice environment, and burnout: literature review. IJRMS 2015;3(8):1825-1831.

11. Farman A, Kousar R, Hussain M, Waqas A, Gillani SA. Impact of job satisfaction on quality of care among nurses on the public hospital of Lahore, Pakistan. Saudi J. Med. Pharm. Sci. 2017;3(6): 511-519.

12. Helbing E, Teems M, Moultrie D. An investigation of job satisfaction among nurses in the emergency department. The ABNF Journal 2017;28(4):103-118.

13. Gillet N, Fouquereau E, Coillot H, Cougot B, Moret L, Dupont S, et al. The effects of work factors on nurses' job satisfaction, quality of care and turnover intentions in oncology. J Adv Nurs 2018;74(5):1208-1219.

14. Seren Intepeler S, Esrefgil G, Yilmazmis F, Bengu N, Gunes Dinc N, Ileri S, ... \& Dirik HF. Role of job satisfaction and work environment on the organizational commitment of nurses: a cross-sectional study. Contemp Nurse 2019;55(4-5):380-390.

15. Seren İntepeler Ş, Güneş N, Bengü N, Yılmazmış F. Bir üniversite hastanesinde çalışan hemşirelerin iş doyumu ve kurumsal bağl1lıklarındaki değişim. Dokuz Eylül Üniversitesi Hemşirelik Fakültesi Elektronik Dergisi 2014;7(1):2-6.

16. Özsoy E, Uslu O, Karakiraz A, Aras M. İş tatmininin ölçümünde ölçek kullanımı: Lisansüstü tezleri üzerinden bir inceleme. İşletme Araştırmaları Dergisi 2014;6(1):232-250.

17. Ulusoy EÇ, Alpar ŞE, Uslusoy EÇ. Hemşirelerde meslektaş dayanışması ve iş doyumu ile ilişkisi. Florence Nightingale Hemşirelik Dergisi 2013;21(3):154-163.

18. Kundak Z, Üzel Taş H, Keleş A, Eğicioğlu H. Bir üniversite hastanesinde hemşirelik mesleğinde iş tatmini ve motivasyon. Kocatepe Tip Dergisi 2015;16(1):1-10.

19. Tambağ H, Kahraman Y, Şahpolat M, Can R. Hemşirelerin çalışma ortamlarının iş doyumu üzerine etkisi. Bakırköy Tıp Dergisi 2015;11(4):143-149.

20. Tilev S, Beydağ KD. Hemşirelerin iş doyum düzeyi. Sağlık ve Hemşirelik Yönetimi Dergisi 2014;3(1):140-147.

21. Yüksel-Kaçan C, Örsal Ö, Köşgeroğlu N. Hemşirelerde İş Doyumu Düzeyinin İncelenmesi. Hemşirelikte Araştırma Geliştirme Dergisi 2016;18(2-3): 1-12.

22. Ergin C. Bir iş doyumu ölçümü olarak İş Betimlemesi Ölçeği: Uyarlama, geçerlik ve güvenirlik çalışması. Türk Psikoloji Dergisi 1997;12(39):25-36.

23. Bekmezci M, Mert İS. Çalışanların görev yaptığı örgüt kademesinin iş tatmin ve örgütsel bağl1lık düzeyleri üzerindeki etkisi. UïİiDIJEAS 2018;17(UİK Özel Sayısı):747-760.

24. Ertürk E, Keçecioğlu T. Çalışanların iş doyumları ile mesleki tükenmişlik düzeyleri arasındaki ilişkiler: Öğretmenler üzerine örnek bir uygulama. Ege Akademik Bakış 2012;12(1):39-52.

25. Toker B. Konaklama işletmelerinde iş doyumu: demografik değişkenlerin iş doyumu faktörlerine etkisi üzerine bir çalışma. Journal of Yaşar University 2007;2(6):591-615.

26. Çakmur H. İş Doyumu kavramı ve değerlendirilmesi. Geliştirilmiş İş Betimlemesi Ölçeği. TAF Preventive Medicine Bulletin 2011;10(6):759-764.

27. Kılıç B, Çakmur H. İş Betimlemesi Ölçeğinin geliştirilmesi. Türk Aile Hek Derg 2011;14(3):124-131.

28. Muya M, Katsuyama K, Özakı F, Aoyama F. Development of a scale measuring the job satisfaction of Japanese hospital nurses. Jpn J Nurs Sci. 2014;11(3):160-170.

29. Türe Yılmaz A, Yıldırım A. Hemşire İş Doyum Ölçeği'nin Türkçe geçerlilik ve güvenirliği. Sağlik ve Hemşirelik Yönetimi Dergisi 2016;3(3):158-168.

30. Mueller JC, McCloskey CW. Nurses job satisfaction: a proposed measure. Nurs Res 1990;39(2):113-117. 
31. El-Jardali F, Dimassi H, Dumit N, Jamal D, Mouro G. A national cross-sectional study on nurses intent to leave and job satisfaction in Lebanon: Implications for policy and practice. BMS Nursing 2009;8:3.

32. Abu Ajamieh AR, Misener T, Haddock KS, Gleaton J. Job satisfaction correlates among Palestinian nurses in the West Bank. Int J Nurs Stud 1996;33(4):422-432.

33. Al-Enezi N, Chowdhury RA, Shah M, Al-Otabi M. Job satisfaction of nurses with multicultural backgrounds: a questionnaire survey in Kuwait. Appl Nurs Res 2009;22:94-100.

34. Abualrub RF, Omari FH, Al Rub AB, Fawzi A. The moderating effect of social support on the stress-satisfaction relationship among Jordanian Hospital nurses. J Nurs Manage 2009;1(7):870-878.

35. El-Jardali F, Alameddine M, Jamal D, Dimassi H, Dumit N, McEwen MK, et al. A national study on nurses retention in healthcare facilities in underserved Areas in Lebanon. Hum Resour Health 2013;11:49

36. Boateng GO, Neilands TB, Frongillo EA, Melgar-Quiñonez HR, Young SL. Best practices for developing and validating scales for health, social, and behavioral research: a primer. Front Public Health 2018;6:Article 149.

37. Tavşancıl E. Tutumların Ölçülmesi ve SPSS ile Veri Analizi. 2. Baskı. İstanbul, Nobel Yayın Dağıtım; 2005: 20.

38. Grant JS, Davis LL. Selection and use of content experts for instrument development. Res Nurs Health 1997;20(3)269-274.

39. Coster WJ, Mancini MC. Recommendations for translation and cross-cultural adaptation of instruments for occupational therapy research and practice. Rev Ter Ocup Univ São Paulo 2015;26(1):50-57.

40. Çapık C, Gözüm S, Aksayan S. Kültürlerarası ölçek uyarlama aşamaları, dil ve kültür uyarlaması: Güncellenmiş rehber. FNJN 2018;26(3):199-210.

41. DeVon HA, Block ME, Moyle- Wright P, Ernst DM, Hayden SJ, Lazzara DJ, et al. A psychometric toolbox for testing validity and reliability. J Nurs Scholarship 2007;39(2):155-164.

42. Polit DF, Beck CT. Nursing Research. Generating and Assessing Evidence for Nursing Practice. $9^{\text {th }}$ ed. Philadelphia, Wolters Kluwer/lippincott Williams \& Wilkins; 2012: 351-378.

43. Alpar R. Uygulamalı İstatistik ve Geçerlik - Güvenirlik. 3. Baskı. Ankara, Detay Yayıncılık; 2014.

44. Güngör D. Psikolojide ölçme araçlarının geliştirilmesi ve uyarlanması kılavuzu. Türk Psikoloji Yazıları 2016;19:104-112.

45. Reisinger Y, Mavondo F. Structural equation modeling: Critical issues and new developments. Journal of Travel \& Tourism Marketing 2007;21(4):41-71.

46. Çapık C. Geçerlik ve güvenirlik çalışmalarında doğrulayıcı faktör analizinin kullanımı. Anadolu Hemşirelik ve Sağlık Bilimleri Dergisi 2014;17(3):196-205.

47. Yılmaz V, Varol S. Hazır yazılımlar ile yapısal eşitlik modellemesi: AMOS, EQS, LISREL. Dumlupınar Üniversitesi Sosyal Bilimler Dergisi 2015;44:28-44.

48. Büyüköztürk Ş. Faktör analizi: Temel kavramlar ve ölçek geliştirmede kullanımı. Kuram ve Uygulamada Eğitim Yönetimi 2002;32:470-483.

49. Polit DF, Beck CT. Hemşirelik Araştırmasının Esasları. Hemşirelik Uygulaması İçin Kanıtın Değerlendirilmesi. Çeviri Editörleri: Aslan Ö, Bebiş H, 8. Basım. Ankara, Pelikan Kitabevi; 2016: 199-213.

50. Wang M, Batt K, Kessler C, Neff A, Iyer NN, Cooper DL, et al. Internal consistency and item-total correlation of patient-reported outcome instruments and hemophilia joint health score v2. 1 in US adult people with hemophilia: results from the pain, functional impairment, and quality of life (P-FiQ) study. Patient Preference Adherence 2017;11:1831-1839.

51. Bolarinwa OA. Principles and methods of validity and reliability testing of questionnaires used in social and health science researches. Niger Postgrad Med J 2015;22(4):195-201.

52. Souza, ACD, Alexandre NMC, \& Guirardello EDB. Psychometric properties in instruments evaluation of reliability and validity. Epidemiol. Serv. Saude 2017;26(3):649-659. 